\title{
Screening of Ethnic Indian Fermented Foods for Effective Phytase Producing Lactic Acid Bacteria for Application in Dephytinization of Phytate Rich Foods
}

\author{
Neha Sharma1, Kanthi Kiran Kondepudi ${ }^{2}$, and Naveen Gupta ${ }^{1^{*}}$ \\ Department of Microbiology, Panjab University, Chandigarh, India \\ ${ }^{2}$ Food and Nutritional Biotechnology, National Agri-Food Biotechnology Institute, Punjab, India \\ *Corresponding authors: ng.puchd@gmail.com \\ ${ }^{\#}$ Equal Contribution \\ Available online at: www.isroset.org \\ Received: 08/Mar/2019, Accepted: 13/Apr/2019, Online: 30/Apr/2019
}

\begin{abstract}
Dephytinization of phytate rich foods is required to increase their nutritional quality. Phytase producing lactic acid bacteria (LAB) are of special interest as this group of organisms are generally regarded as safe (GRAS) for human consumption, moreover they have an added characteristic of acting as probiotics. Despite being highly advantageous very few reports are there on LAB producing phytase with desired characteristics. In present study ethnic fermented foods from various regions of India were analyzed for phytase producing LAB. Seventeen strains of LAB were isolated from various fermented foods. Out of which seven isolates showed the ability to produce phytase. Detailed analysis confirmed all the isolates to have characteristics typical to that of LAB. Some of the LAB isolates (KA1, SA2, SM1) showed the ability to produce phytase effectively. All the isolates hydrolysed phytate in soy milk and rice bran therefore they can be good candidates for their application in the processing of phytate rich foods.
\end{abstract}

Keywords: Fermented food, Lactic acid bacteria, Nutrient deficiency, Phytase, Phytate.

\section{INTRODUCTION}

In plant-based foods, phosphorous (1-5\% by weight) is present in bounded form with various other minerals and is known as phytate [36]. Phytate, an anti-nutrient molecule is a myo-inositol phosphate derivative containing six phosphate groups. Phytate rich foods pose nutrition deficit due to capability of phytate to chelate with various divalent cations and protein moieties. This property of phytate makes these minerals and other forms of nutrients non-available for uptake and absorption after ingestion [9]. Although some fraction of phytate gets hydrolysed during various food processing steps/processes like soaking, germination, cooking, fermentation etc. The undegraded portion of phytate causes various malnutrition associated problems [22]. Most viable alternative to solubilise nutrients in phytate rich foods is to hydrolyse phytate by enzymatic treatment. Enzyme(s) responsible for phytate hydrolysis is a class of phosphatases called phytase(s) [1]. Phytases have been reported from number of microorganisms $[4,18]$ but they are not useful for food processing because of safety issues associated with them [27]. Lactic acid bacteria (LAB) are a class of microorganisms which has been generally regarded as safe (GRAS) for human use [19].Moreover they are also known to have probiotic properties which are associated with number of health benefits [21]. Therefore phytase(s) producing $\mathrm{LAB}$ or enzyme from such organisms can be applied safely for the food processing. Although some phytase producing $\mathrm{LAB}$ have been reported but most of them have limitations such as producing the enzyme intracellularly, low enzyme yield etc. [25, 34]. In this regard search is still on to isolate novel phytase producing LAB which can be used for the food processing.

Since time immemorial fermented foods have been a rich source of lactic acid bacteria [13, 33]. India is a land rich in diverse traditional ethnic fermented foods [30]. Most of the time sources for these fermented foods are phytate rich substrates $[3,26]$ therefore they can be a potent source for the isolation of phytase producing LAB. But there are very limited reports on exploration of these foods for the isolation of phytase producing LAB [7, 17, 24]. As no extensive study is available, the present study was aimed for the isolation and characterization of phytase producing lactic acid bacteria which can be used in various food applications. In the present study, wide variety of ethnic Indian fermented foods were screened for lactic acid bacteria. These bacteria were further shortlisted on the basis of their phytase producing potential and were studied for various morphological and biochemical characteristics. Application of these isolates in soy milk and rice bran showed significant phytate hydrolysis in terms of increase in the content of solubilized inorganic phosphate which indicated their potential for increasing the nutritional quality of these foods. 


\section{MATERIALS AND METHODS}

\section{Collection of samples}

Samples of ethnic fermented foods were collected from various parts of India; some of the foods were prepared and fermented in the laboratory (Table 1). Samples were brought in sterilized vials and polythene bags to the laboratory and were processed immediately.

\section{Isolation of lactic acid bacteria}

Samples were enriched by inoculating $1 \%$ of the sample in de Mann Rogosa Sharpe (MRS) broth and incubating for 48h. Enriched samples were screened for LAB by inoculating appropriate diluted samples on MRS agar. Isolates showing different colony morphology were selected and confirmed for the production of lactic acid by streaking on MRS agar plates containing $1 \% \mathrm{CaCO}_{3}$. Isolates showing clear zone around colonies were selected [35]. The selected colonies were further purified by tertiary plating method. These cultures were preserved in $40 \%$ glycerol at $-80^{\circ} \mathrm{C}$ till further use.

\section{Screening of phytase producing lactic acid bacteria}

Selected isolates were tested for phytase producing potential. These isolates were spotted on modified MRS agar in which MRS medium was supplemented with $0.2 \mathrm{M}$ sodium phytate, $2 \mathrm{mM}$ calcium chloride and $0.1 \mathrm{M} 3-[\mathrm{N}$ Morpholino] propanesulfonic acid, MOPS [14]. The colonies showing zone of phytate hydrolysis were selected. To eliminate the possibility of zones due to acid producing ability, plates were flooded with aqueous cobalt chloride solution $(2 \% \mathrm{w} / \mathrm{v})$ for 5 minutes at room temperature. Then the solution was replaced with a fresh solution containing $\mathrm{v} / \mathrm{v}$ of $6.25 \%(\mathrm{w} / \mathrm{v})$ aqueous ammonium molybdate solution $+0.42 \%(\mathrm{w} / \mathrm{v})$ ammonium vanadate solution for another 5 minutes. The phytate degradation was confirmed by presence of clear zones around colonies [6].

\section{Morphological and Biochemical characterization}

Gram character and morphology of the isolates was analysed by doing Gram staining. Spore formation was checked by doing spore staining with stationary phase culture. All biochemical tests and carbohydrate utilization was performed according to Bergey'smanual [15].

\section{Dephytinization of Soymilk and rice bran}

Dephytinization experiments were carried out with all the selected isolates. $5 \mathrm{ml}$ of soymilk and $5 \mathrm{~g}$ of rice bran was inoculated with individual isolates and incubated at $37^{\circ} \mathrm{C}$ for 24h. Uninoculated samples were incubated as controls. The samples were drawn and were analysed for amount of inorganic phosphate $(\mathrm{Pi})$ liberated.

\section{RESULTS AND DISCUSSION}

Phytase(s) producing microorganisms have wide application in food industry [37]. Phytase producing lactic acid bacteria (LAB) are of special interest due to their acceptability regarding safety aspects and probiotic nature [33]. But there are very few reports on $\mathrm{LAB}$ which are known to produce phytases with suitable yield/characteristics so that they can be applied for hydrolysis of phytate in food processing. Fermented foods are immensely associated with numerous lactic acid bacteria [32]. Different regions of India are a rich source of diverse phytate rich fermented foods, but very limited reports are there on the isolation of phytases producing LAB from these foods [2, 8, 35]. Therefore, fermented foods were collected from various regions of India viz., Sauerkraut and Kanjika from North India; Khalpi from Hilly areas of North India; Goyang and Soibum from North East India; Curd, sourdough and fermented soy milk were prepared in the laboratory (Table 1).

Food samples were enriched in De Man, Rogosa and Sharpe (MRS) broth which is selective for lactic acid bacteria [10] and then screened for LAB on MRS agar. Seventeen isolates with varied colony morphology from different food samples were selected. These isolates were further confirmed for the production of lactic acid by streaking on MRS medium supplemented with $\mathrm{CaCO}_{3}$ all seventeen isolates showed acid production in terms of zone of clearance against opaque background (Fig.1). Similar procedure has been used by various workers for the isolation of $\mathrm{LAB}$ from fermented foods $[2,8,20,35]$.

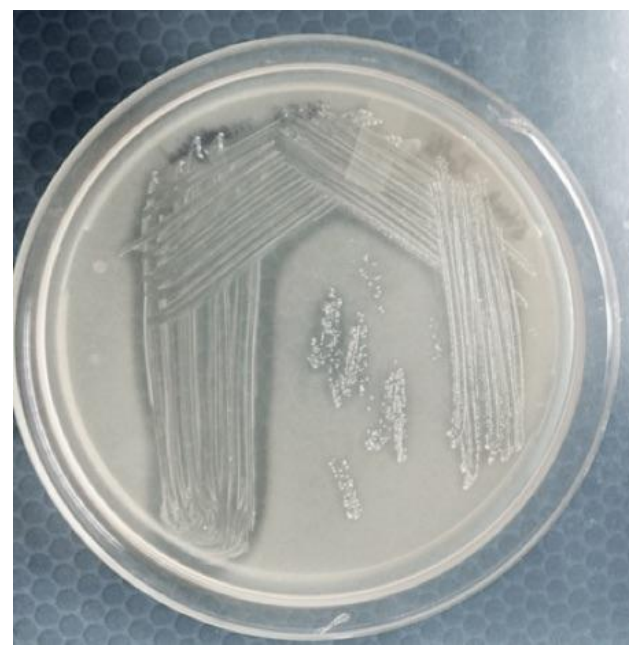

Fig.1: Zone of lactic acid production on $\mathrm{MRS}+\mathrm{CaCO}_{3}$ medium 
As primary objective of the study was to isolate phytase producing $\mathrm{LAB}$ therefore selected isolates from MRS plates were screened for the production of phytase on modified MRS agar medium containing sodium phytate [14]. Seven isolates showed zone of phytate hydrolysis. To confirm and eliminate false positive results plates were counter-stained with procedure given by Bae et al. (1999) [6] using solutions of cobalt chloride and ammonium molybdate+ammonium vanadate. Production of phytase by all seven isolates was confirmed as all showed the zone of clearance in this confirmatory test also. Phytase positive isolates were categorized as potent (KA1), moderate (SA2, SM1) and weak (SA1, KA2, SO1, SM2) producer of enzyme depending on the zone of the hydrolysis (Fig. 2; Table 1).

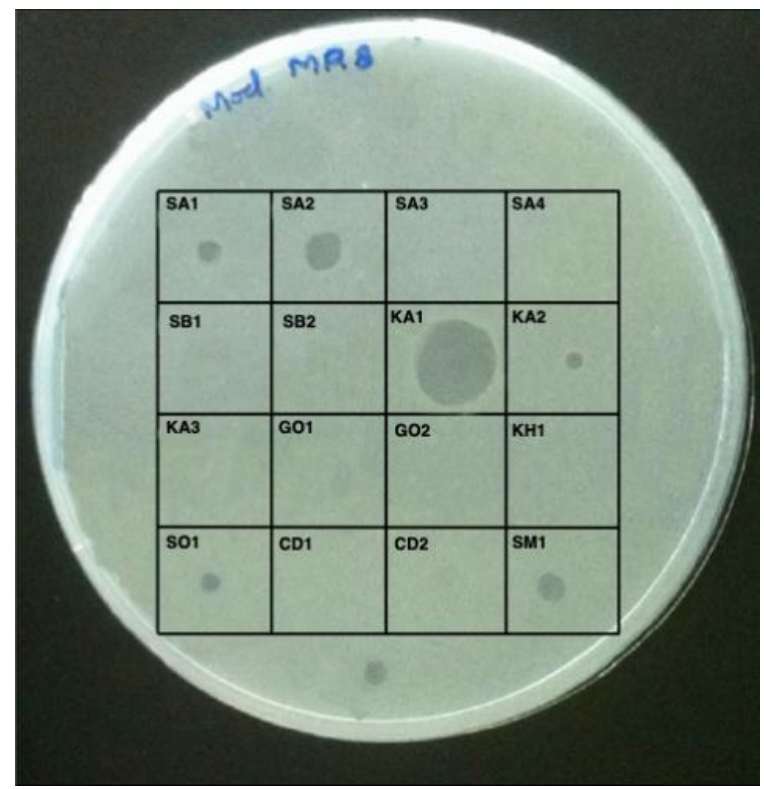

Fig 2: Zones of phytate degradation on modified MRS agar; counterstained with cobalt chloride and ammonium molybdate + ammonium vanadate
Table 1: Phytase producing lactic acid bacteria from ethnic Indian fermented foods

\begin{tabular}{|c|c|c|c|}
\hline S.No & Isolate & Source & Phytate degradation \\
\hline 1 & SA1 & \multirow{4}{*}{ Sauerkraut } & + \\
\hline 2 & SA2 & & + \\
\hline 3 & SA3 & & - \\
\hline 4 & SA4 & & - \\
\hline 5 & SB1 & \multirow{2}{*}{ Sourdough Bread } & - \\
\hline 6 & SB2 & & - \\
\hline 7 & KA1 & \multirow{3}{*}{ Kanjika } & + \\
\hline 8 & KA2 & & + \\
\hline 9 & KA3 & & - \\
\hline $\begin{array}{c}10 \\
11\end{array}$ & $\begin{array}{l}\text { GO1 } \\
\text { GO2 }\end{array}$ & Goyang & - \\
\hline 12 & KH1 & Khalpi & - \\
\hline 13 & SO1 & Soibum & + \\
\hline $\begin{array}{l}14 \\
15\end{array}$ & $\begin{array}{l}\text { CD1 } \\
\text { CD2 }\end{array}$ & Curd & - \\
\hline $\begin{array}{l}16 \\
17 \\
\end{array}$ & $\begin{array}{l}\text { SM1 } \\
\text { SM2 }\end{array}$ & Soymilk & $\begin{array}{l}+ \\
+\end{array}$ \\
\hline
\end{tabular}

For the application of any isolate it is required to have its complete characterization [11]. Therefore to further confirm the identity of phytase positive isolates their detailed identification was done by morphological and biochemical characterization (Table 2). All the isolates were found to be Gram positive, non-motile with no catalase activity, these characteristics have been reported to be typical to that of LAB [15,19,27,35]. Rod [5] as well as cocci [28] shaped LAB have been reported; out of seven 5 isolates were cocci and two were of rod shape. Biochemical tests of all the isolates (Table 2) were also distinctive to that of LAB [12].

Carbohydrate utilization pattern is other important criteria for the identification and characterization of LAB [2]. Sugar utilization pattern showed that all the isolates were able to ferment glucose, galactose, fructose, mannose, ribose, amygdalin, arbutin, salicin, cellobiose, maltose, lactose, melibiose, saccharose, trehalose and melezitose and esculin citrate de fer, while the other sugars showed varied fermentative responses among the isolates (Table 3). All the isolates were able to deaminate arginine. This capacity is used to differentiate heterofermentative ability of lactobacilli [31]. 
Table 2: Morphological and biochemical characteristics of phytase producing LAB isolates from ethnic Indian fermented foods

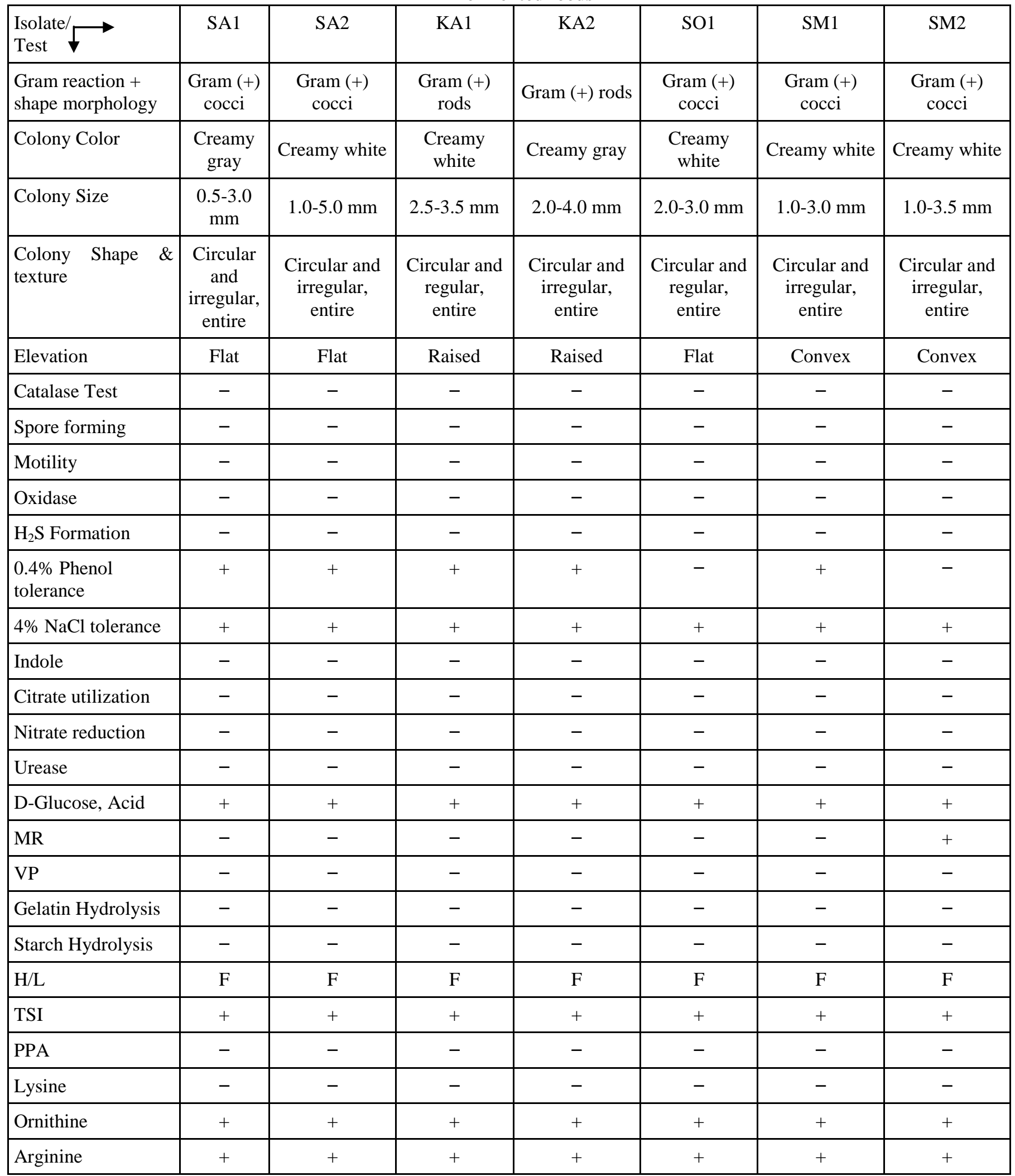

$(-)=$ negative $;(+)=$ positive $; \mathrm{F}=$ fermentation 
Table 3: Carbohydrate utilization pattern of phytase producing LAB from ethnic Indian fermented foods

\begin{tabular}{|c|c|c|c|c|c|c|c|}
\hline $\begin{array}{l}\text { Isolate/ } \\
\text { Test }\end{array}$ & SA1 & SA2 & KA1 & KA2 & SO1 & SM1 & $\mathrm{SM} 2$ \\
\hline Control & - & - & - & - & - & - & - \\
\hline Glycerol & - & - & - & + & - & - & - \\
\hline Erythritol & - & - & - & - & - & - & - \\
\hline D-arabinose & - & - & - & - & - & - & - \\
\hline L-arabinose & \pm & + & + & - & - & + & - \\
\hline D-ribose & + & + & - & + & + & + & + \\
\hline D-xylose & + & + & + & - & - & - & - \\
\hline L-xylose & - & - & - & - & - & - & - \\
\hline D-adonitol & - & - & - & - & - & - & - \\
\hline Methyl- $\beta$ D-xylopyranoside & - & - & - & - & - & - & - \\
\hline D-galactose & + & + & + & + & + & - & + \\
\hline D-glucose & + & + & + & + & + & + & + \\
\hline D-fructose & + & + & + & + & + & + & + \\
\hline D-mannose & + & + & + & + & + & + & + \\
\hline L-sorbose & - & - & - & - & - & - & + \\
\hline L-rhamnose & - & - & w+ & - & - & - & - \\
\hline Dulcitol & + & - & - & - & - & - & - \\
\hline Inositol & - & - & - & - & - & - & - \\
\hline Mannitol & + & + & + & + & - & - & + \\
\hline Sorbitol & + & - & - & + & - & - & - \\
\hline Methy- $\alpha \mathrm{D}$-mannopyranoside & - & + & - & - & - & - & - \\
\hline Methy- $\alpha \mathrm{D}$-glucopyranoside & - & \pm & vw+ & - & - & + & - \\
\hline N-Acetyl-Glucosamine & + & + & + & + & + & - & + \\
\hline Amygdalin & - & + & + & + & + & + & - \\
\hline Arbutin & + & + & + & + & + & + & - \\
\hline Esculin citrate de fer & + & + & + & + & + & + & + \\
\hline Salicin & + & + & + & + & + & + & + \\
\hline D-cellobiose & + & + & + & + & + & - & - \\
\hline D-Maltose & + & + & + & + & + & - & - \\
\hline D-Lactose & - & + & + & + & + & + & + \\
\hline D-Melibiose & - & + & + & + & + & + & - \\
\hline D-Saccharose & + & + & + & + & + & + & - \\
\hline
\end{tabular}




\begin{tabular}{|l|c|c|c|c|c|c|c|}
\hline D-Trehalose & + & + & + & + & + & - & + \\
\hline Inulin & + & - & $\mathrm{w}$ & - & - & - & - \\
\hline D-Melezitose & + & + & + & + & + & - & - \\
\hline D-Raffinose & - & + & $\mathrm{w}$ & - & - & - & - \\
\hline Amidon & - & - & - & - & - & - & - \\
\hline Glycogen & - & - & - & - & - & - & - \\
\hline Xylitol & - & - & - & - & - & - & - \\
\hline Gentiobiose & - & + & + & + & + & + & - \\
\hline D-Turanose & + & + & + & - & - & - & + \\
\hline D-lyxose & - & - & - & - & - & - & - \\
\hline D-tagatose & + & - & - & + & + & - & + \\
\hline D-fucose & - & - & - & - & - & - & - \\
\hline L-fucose & - & - & - & - & - & - & - \\
\hline D-arabitol & - & \pm & - & - & - & - & - \\
\hline L-arabitol & - & - & - & - & - & - & - \\
\hline Potassium gluconate & \pm & \pm & - & - & - & - & - \\
\hline 2-Keto-Gluconate & - & + & + & - & - & - \\
\hline
\end{tabular}

$(+)$ : positive; $(-)$ : negative; $\left(\mathrm{w}^{+}\right)$: weak positive; $\left(\mathrm{vw}^{+}\right)$: very weak positive; $( \pm)$: doubtful

All these results confirmed that all the phytase producing isolates screened for fermented ethnic Indian foods were typical lactic acid bacteria.

Goal of the study was to isolate the phytase producing LAB for dephytinization of phytate rich foods. Soy milk and rice bran are known to have high content of phytate [23]. All the isolates were tested for their ability to hydrolyse phytate in these foods in terms of release of inorganic phosphate $(\mathrm{Pi})$. Treatment of soy milk as well as rice bran with all the bacterial isolates led to increase in the level of Pi. Phytate hydrolysis was more with KA1, SA2 and SM1 than other isolates which correlated with the results of phytate degradation on MRS sodium phytate agar medium. Detailed experiments for the application of these isolates in food processing are being carried out.

\section{CONCLUSION}

Phytate containing ethnic Indian ferments foods are a rich source of phytase producing lactic acid bacteria. A wide variety of LAB from these foods were isolated with good phytase producing capacity. In identification analysis isolates showed characteristics typical to that of LAB. Application of these isolates in soy milk and rice bran showed significant phytate hydrolysis indicating that they can be used for increasing the nutritional quality of these foods.

\section{Conflict of interest}

None

\section{Acknowledgement}

This work was carried out in the Department of Microbiology, Panjab University, Chandigarh and National Agri-Food Biotechnology Institute, Mohali.

\section{Funding}

The authors would like to thank the INSPIRE unit, Department of Science and Technology (DST-INSPIRE), Government of India, New Delhi, India and Dr. Kanthi Kiran Kondepudi, National Agri-Food Biotechnology Institute for the financial support.

\section{REFERENCES}

[1]. S Afinah, A.M. Yazid, M.H. Anis Shobirin, M. Shuhaimi, "Phytase: application in food industry", International Food Research Journal, Vol. 17, Issue., 1, pp.13-21, 2010.

[2]. A.A Ali, "Isolation and Identification of lactic acid bacteria isolated from traditional drinking yoghurt in Khartoum State, Sudan", Current research in Bacteriology, Vol. 4, Issue., 1, pp.1622, 2011.

[3]. G.A. Annor, K.T. Debrah, A. Essen, "Mineral and phytate contents of some prepared popular Ghanaian foods", SpringerPlus, Vol. 5, Issue., 1, pp. 581, 2016. 
[4]. G.E. Awad, M.M. Helal, E.N. Danial, M.A. Esawy, "Optimization of phytase production by Penicillium purpurogenum GE1 under solid state fermentation by using BoxBehnken design", Saudi journal of biological sciences, Vol. 21, Issue., 1, pp. 81-88, 2014.

[5]. L. Axelsson, "Lactic acid bacteria: classification and physiology", Food Science and Technology-New York-Marcel Dekker, Vol. 139, pp. 1-66, 2004.

[6]. H.D. Bae, L.J. Yanke, K.J. Cheng, L.B. Selinger, "A novel staining method for detecting phytase activity", Journal of Microbiological Methods, Vol. 39, Issue., 1, pp. 17-22, 1999.

[7]. S. Basu, S.K. Tomar, S. Hati, "Isolation and identification of phytate-degrading lactobacilli from Indian cereal-based fermented milk product-" Raabadi"." International Journal of Fermented Foods, Vol. 4, Issue., 1/2, pp. 35, 2015.

[8]. Y.S. Chen, F. Yanagida, J.S. Hsu, "Isolation and characterization of lactic acid bacteria from dochi (fermented black beans), a traditional fermented food in Taiwan", Letters in applied microbiology, Vol. 43, Issue., 2, pp. 229-235, 2006.

[9]. A. Das, U. Raychaudhuri, R. Chakraborty, "Cereal based functional food of Indian subcontinent: a review", Journal of food science and technology, Vol. 49, Issue., 6, pp. 665-672, 2012.

[10]. J.C. De Man, D. Rogosa, M.E. Sharpe, "A medium for the cultivation of lactobacilli", Journal of applied Bacteriology, Vol. 23, Issue., 1, pp. 130-135, 1960.

[11]. M.J. Desai, D.W. Armstrong, "Separation, identification, and characterization of microorganisms by capillary electrophoresis", Microbiology and Molecular Biology Reviews, Vol. 67, Issue., 1, pp. 38-51, 2003.

[12]. G. Goswami, S.S Bora, A. Parveen, R.C. Boro, M. Barooah, "Identification and functional properties of dominant lactic acid bacteria isolated from Kahudi, a traditional rapeseed fermented food product of Assam, India", Journal of Ethnic Foods, Vol. 4, Issue., 3, pp. 187-197, 2017.

[13]. M.R. Guasch-Jané, C. Andrés-Lacueva， O. Jáuregui， R.M. Lamuela-Raventós, "First evidence of white wine in ancient Egypt from Tutankhamun's tomb. Journal of archaeological science", Vol. 33, Issue., 8, pp. 1075-80, 2006.

[14]. M. Haros, M. Bielecka, Y. Sanz, "Phytase activity as a novel metabolic feature in Bifidobacterium", FEMS microbiology letters, Vol. 247, Issue., 2, pp. 231-239, 2005.

[15]. J.G. Holt, N.R. Krieg, P.H.A. Sneathm, J.T. Staley, S.T. Williams, "Bergey's manual of determinative bacteriology", 9th edn. Williams and Williams, Baltimore, 1994.

[16]. W.H. Holzapfel, P. Haberer, R. Geisen, J. Björkroth, U. Schillinger, "Taxonomy and important features of probiotic microorganisms in food and nutrition", The American journal of clinical nutrition, Vol. 73, Issue., 2, pp. 365s-373s, 2001.

[17].Z. Khodaii Z, M. Mehrabani Natanzi, M.H. Naseri, M. Goudarzvand, H. Dodson, A.M. Snelling, "Phytase activity of lactic acid bacteria isolated from dairy and pharmaceutical probiotic products", International Journal of Enteric Pathogens, Vol. 1, Issue., 1, pp. 12-16, 2013.

[18]. Y.H. Kim, M.N. Gwon, S.Y. Yang, T.K. Park, C.G. Kim, C.W Kim, M.D. Song, "Isolation of phytase-producing Pseudomonas $s p$. and optimization of its phytase production". J.of microbiology and biotechnology, Vol. 12, Issue., 2, pp. 279-285, 2002.

[19]. W.N. Konings, J. Kok, O.P. Kuipers, B. Poolman, "Lactic acid bacteria: the bugs of the new millennium", Current opinion in microbiology, Vol. 3, Issue., 3, pp.276-282, 2000.

[20]. V. Kumar, A. Kumari, K. Angmo, T.C. Bhalla, "Isolation and characterization of lactic acid bacteria from traditional pickles of Himachal Pradesh, India". Journal of food science and technology, Vol. 54, Issue., 7, pp. 1945-52, 2017.
[21]. M.I. Masood, M.I. Qadir, J.H. Shirazi, I.U. Khan, "Beneficial effects of lactic acid bacteria on human beings", Critical reviews in microbiology, Vol. 37, Issue., 1, pp. 91-98, 2011.

[22]. J.E. Mayer, W.H. Pfeiffer, P. Beyer, "Biofortified crops to alleviate micronutrient malnutrition", Current opinion in plant biology, Vol. 11, Issue., 2, pp. 166-170, 2008.

[23]. J.M. Sanz-Penella, M. Haros, "Whole grain and phytatedegrading human bifidobacteria", In Wheat and rice in disease prevention and health, Academic Press, pp. 17-31, 2014.

[24]. L. Nuobariene, D. Cizeikiene, E. Gradzeviciute, A.S. Hansen, S.K. Rasmussen, G. Juodeikiene, F.K. Vogensen, "Phytase-active lactic acid bacteria from sourdoughs: Isolation and identification", LWT-Food Science and Technology, Vol. 63, Issue., 1, pp. 766-772, 2015.

[25]. M.C. Palacios, M. Haros, C.M. Rosell, Y. Sanz, "Characterization of an acid phosphatase from Lactobacillus pentosus: regulation and biochemical properties", Journal of Applied Microbiology, Vol. 98, Issue., 1, pp. 229-237, 2005.

[26]. B.Q. Phillippy, C.J. Wyatt, "Degradation of phytate in foods by phytases in fruit and vegetable extracts", Journal of food science, Vol. 66, Issue., 4, pp. 535-539, 2001.

[27]. P. Priyodip, P.Y. Prakash, S. Balaji, "Phytases of probiotic bacteria: characteristics and beneficial aspects", Indian journal of microbiology, Vol. 57, Issue., 2, pp. 148-154, 2017.

[28]. S. Salminen, A. Von Wright, "Lactic acid bacteria: microbiological and functional aspects", CRC Press, 2004.

[29]. A. Sathyapriya, A. Anitha, "Assessment of Probiotic Potential Leuconostoc mesenteroides from Natural Microbiota" International Journal of Scientific Research in Biological Sciences, Vol. 5, Issue., 6, pp. 26-33, 2018.

[30]. R. Satish Kumar, P. Kanmani, N. Yuvaraj, K.A. Paari, V. Pattukumar, V. Arul, "Traditional Indian fermented foods: a rich source of lactic acid bacteria", International journal of food sciences and nutrition, Vol. 64, Issue., 4, pp. 415-428, 2013.

[31]. U. Schillinger, F.K. Lücke, "Antibacterial activity of Lactobacillus sake isolated from meat", Applied and Environmental Microbiology, Vol. 55, Issue., 8, pp. 1901-1906, 1989.

[32]. R. Scott, W.C. Sullivan, "Ecology of fermented foods", Human Ecology Review, Vol. 1, pp. 25-31, 2008.

[33]. I. Siro, E. Kápolna, B. Kápolna, A. Lugasi, “Functional food. Product development, marketing and consumer acceptance-A review", Appetite, Vol. 51, Issue., 3, pp. 456-467, 2008.

[34]. M. Sumengen, S. Dincer, A. Kaya, "Production and characterization of phytase from Lactobacillus plantarum", Food biotechnology, Vol. 27, Issue., 2, pp. 105-108, 2013.

[35]. J.P. Tamang, B. Tamang, U. Schillinger, C.M. Franz, M. Gores, W.H. Holzapfel, "Identification of predominant lactic acid bacteria isolated from traditionally fermented vegetable products of the Eastern Himalayas", International journal of food microbiology, Vol. 105, Issue., 3, pp. 347-356, 2005.

[36].P. Vats, U.C. Banerjee UC, "Production studies and catalytic properties of phytases (myo-inositolhexakisphosphate phosphohydrolases): an overview", Enzyme and Microbial Technology, Vol. 35, Issue., 1, pp. 3-14, 2004.

[37]. A.A. Yousten, J.L. Johnson, M.A. Salin, "Oxygen metabolism of catalase-negative and catalase-positive strains of Lactobacillus plantarum", Journal of bacteriology, Vol. 123, Issue., 1, pp. 242$247,1975$.

[38]. C. Zhenming, L. Zhiqiang, G. Lingmei, G. Fang, M.A. Chunling, W. Xianghong, L.I. Haifeng, "Marine yeasts and their applications in mariculture", Journal of Ocean University of China, Vol. 5, Issue., 3, pp. 251-256, 2006. 